Ekonomia - Wroclaw Economic Review 23/1 (2017)

Acta Universitatis Wratislaviensis

No 3754

DOI: 10.19195/2084-4093.23.1.5

\author{
Aleksandra Królak \\ Politechnika Łódzka \\ aleksandra.krolak@p.lodz.pl
}

\title{
Ocena wybranych platform do e-learningu pod względem dostępności dla osób z niepełnosprawnościami i zgodności z zasadami projektowania uniwersalnego
}

\author{
JEL Classification: I14, I21, I24
}

Keywords: Learning Management System, e-learning, universal design for ICT, W3C, ATAG, education of the disabled

\begin{abstract}
Accessibility and Universal Design Rules Implementation in Selected e-Learning Platforms

Popularity of using learning management systems (LMS) is increasing all over the world. The main function of such tools is to facilitate teaching and learning and enable distance education. It is therefore very important to adjust the e-learning platforms to the needs of students and teachers with disabilities. In this paper the rules of universal design for ICT are presented and World Wide Web Consortium (W3C) recommendations for designing web content are discussed. Five e-learning platforms were tested if they fulfill the requirements of abovementioned regulations: WIKAMP, Moodle, Sakai, Fronter and ItsLearning. The results of this analysis are presented and discussed.
\end{abstract}

\section{Wprowadzenie}

Zmiany w systemie edukacji w krajach rozwiniętych w ciągu ostatnich kilkunastu lat indukują potrzebę wprowadzania do szkół technologii informatycznych i komunikacyjnych. Umożliwiają one wspomaganie nauczania oraz naukę na odległość, dlatego powinny być dostępne dla wszystkich grup użytkowników, także 
tych z niepełnosprawnościami. Platformy edukacyjne, od kilku lat wprowadzane do polskich szkół i uczelni, powoli stają się nieodzownym narzędziem ułatwiającym zarówno nauczanie, jaki i uczenie się. $\mathrm{Z}$ względu na ich funkcje systemy e-learningowe powinny być dostosowane do potrzeb i możliwości uczniów i nauczycieli.

Według Europejskiego Ankietowego Badania Zdrowia (Główny Urząd Statystyczny, 2011) pod koniec 2009 r. prawne orzeczenie o niepełnosprawności miało prawie 4,2 mln Polaków, w tym około 184 tysięcy dzieci do lat 14 . W grupach wiekowych 15-19 lat oraz 20-24 lat odsetek młodzieży mającej poważne ograniczenia $\mathrm{w}$ wykonywaniu codziennych czynności z powodu niepełnosprawności wynosił odpowiednio 2,6\% i 2,2\%. Oznacza to, że liczba dzieci i młodzieży z niepełnosprawnościami w wieku szkolnym wynosiła w roku 2009 ok. 300 tys. Odpowiednie zaprojektowanie platform edukacyjnych zapewniających dostęp do ich pełnej funkcjonalności pozwalałoby tej grupie użytkowników na poprawienie jakości ich nauczania.

W literaturze można znaleźć publikacje na temat oceny dostępności platform edukacyjnych, w których autorzy skupiają się na analizie tylko jednej grupy użytkowników, na przykład uczniów z dysleksją (opisanych w Habib et al. 2012, s. 574), uczniów niedowidzących i niewidomych (Ulbricht et al., 2012, s. 138), uczniów niesłyszących (Debevc, Stjepanovič, Holzinger, 2012, s. 35) lub nauczycieli z niepełnosprawnościami (Chen, Sanderson, Kessel, 2013, s. 437). W niniejszym artykule przedstawiono ogólną analizę wybranych pięciu platform edukacyjnych: WIKAMP, Moodle, Sakai, Fronter i ItsLearning z perspektywy ucznia oraz nauczyciela pod względem dostępności, zgodności z zasadami projektowania uniwersalnego oraz zastosowania się do rekomendacji World Wide Web Consortium (W3C) dotyczącej narzędzi autorskich ATAG (ang. Authoring Tool Accessibility Guidelines).

\section{Dostępność internetowych platform edukacyjnych}

Publikacje dotyczące dostępności internetowych platform edukacyjnych pokazują, że wzrasta złożoność tych systemów, co wiąże się z wzrostem poziomu trudności ich obsługi, szczególnie dla osób z niepełnosprawnościami. Jednocześnie systemy e-learningowe wspomagają proces nauczania w sześciu dziedzinach zdefiniowanych w badaniach (Kicińska, 2000):

— aktywizacyjno-motywacyjna - pobudzanie zainteresowania uczniów i wyzwalanie ich aktywności;

— poznawczo-twórcza — źródło wiedzy, którą wykorzystuje następnie do rozwiązania problemów; niów;

— ćwiczeniowa - ułatwiają samodzielne wykonywanie zadań przez ucz- 
— kontrolna - ułatwiają przeprowadzanie testów dydaktycznych, analizowanie wyników, tworzenie bazy danych zadań testowych, a jednocześnie pozwala na łatwiejsze monitorowanie zaległości uczniów;

— wychowawcza - pozwala na stworzenie dobrych warunków oddziaływania na osobowość ucznia;

— terapeutyczna - umożliwia usuwanie lub pokonywanie zaburzeń rozwojowych.

Zwiększenie dostępności (ang. accessibility) i użyteczności (ang. usability) internetowych platform edukacyjnych jest bardzo istotnym elementem w poprawie jakości nauczania szczególnie osób niepełnosprawnych. Istnieje wiele narzędzi, dokumentów i rekomendacji pomocnych w tworzeniu bardziej dostępnych narzędzi informatycznych. Należą do nich rekomendacje World Wide Web Consortium (W3C) takie jak ATAG, WCAG, UAAG i ARIA oraz standardy dotyczące dostępności: ISO 9241-171 odnoszący się do ergonomii interakcji człowiek-komputer, ISO/IEC 24751-1 odnoszący się do dostępności i dostosowywania narzędzi do e-learningu, część druga i trzecia ISO/IEC 24751 odnoszące się do „dostępu dla wszystkich" źródeł cyfrowych. Dostępne są też narzędzia do ewaluacji dostępności platform edukacyjnych i treści internetowych, np. WAVE, AChecker oraz Cynthia.

Lista zaleceń dotyczących dostosowania platform edukacyjnych dla niedowidzących i niewidomych użytkowników została przedstawiona w publikacji (Periša, Peraković, Remenar, 2011, s. 115). Zawiera ona rekomendacje odnośnie do architektury stron internetowych, nawigacji w systemie, rozmieszczenia elementów w graficznym interfejsie użytkownika, skrótów klawiszowych oraz dźwiękowej informacji zwrotnej. Tworzone są też narzędzia ułatwiające przygotowywanie internetowych kursów dostosowanych do potrzeb i możliwości osób z niepełnosprawnościami. Seale i Cooper (Seale, Cooper, 2010, s. 1107) zaproponowali połączenie typowych narzędzi dydaktycznych ze specjalistycznymi rozwiązaniami do komunikacji człowiek-komputer, przeznaczonymi dla osób z niepełnosprawnościami. W artykule (Ulbricht et al., 2012, s. 138) przedstawiony jest opis dodatku dla platformy edukacyjnej Moodle opracowany dla osób niewidomych. Innym rozszerzeniem dla platformy Moodle jest Moodle ${ }^{\text {Acc+ }}$ (Laabidi et al., 2014, s. 29) oferujący dodatkowe funkcjonalności, takie jak: asystent ucznia, asystent tworzenia zawartości przedmiotu, generator kursów oraz narzędzie do ewaluacji dostępności platformy. Rozszerzenie Moodle ${ }^{\text {Acc }}$ pozwala na spersonalizowanie platformy po wybraniu przez użytkownika rodzaju niepełnosprawności, co ułatwia uczniom korzystanie z narzędzi edukacyjnych.

\section{Metodologia}

W celu oceny wybranych platform e-learningowych pod względem dostępności i użyteczności przygotowano dwa scenariusze - dla ucznia i dla nauczyciela, 
które przedstawione są w tabeli 1. Zadaniem użytkowników było zapisanie swoich subiektywnych odczuć podczas pracy z każdą z wybranych platform e-learningowych oraz ocenienie, czy możliwe jest wykonanie zadania. Otrzymane wyniki zostały wykorzystane do oceny wybranych platform zgodnie z wybranymi punktami rekomendacji ATAG oraz zasad projektowania uniwersalnego.

Tabela 1. Scenariusz testów platform e-learningowych dla ucznia i nauczyciela

\begin{tabular}{|c|c|}
\hline Uczeń & Nauczyciel \\
\hline 1. Zaloguj się & 1. Zaloguj się \\
\hline $\begin{array}{l}\text { 2. Dostosuj wygląd platform (zmień prefer- } \\
\text { encje) }\end{array}$ & $\begin{array}{l}\text { 2. Dostosuj wygląd platform (zmień prefer- } \\
\text { encje) }\end{array}$ \\
\hline 3. Zmień dane użytkownika & 3. Zmień dane użytkownika \\
\hline 4. Wybierz przedmiot & 4. Wybierz przedmiot \\
\hline 5. Otwórz plik z materiałem do przedmiotu & $\begin{array}{l}\text { 5. Załaduj plik tekstowy (doc, docx, odt, } \\
\text { PDF) z materiałem do przedmiotu }\end{array}$ \\
\hline 6. Otwórz zadanie & $\begin{array}{l}\text { 6. Załaduj obraz jako materiał do przedmio- } \\
\text { tu i dodaj tekst alternatywny }\end{array}$ \\
\hline $\begin{array}{l}\text { 7. Załaduj plik tekstowy (doc, docx, odt, } \\
\text { PDF) z rozwiązaniem zadania }\end{array}$ & $\begin{array}{l}\text { 7. Załaduj plik multimedialny jako materiał } \\
\text { do przedmiotu i dodaj tekst alternatywny }\end{array}$ \\
\hline $\begin{array}{l}\text { 8. Załaduj obraz jako rozwiązanie zadania i } \\
\text { dodaj opis elementu }\end{array}$ & $\begin{array}{l}\text { 8. Utwórz zadanie i sformatuj tekst wg. } \\
\text { wzoru }\end{array}$ \\
\hline $\begin{array}{l}\text { 9. Załaduj plik multimedialny jako rozwią- } \\
\text { zanie zadania i dodaj tekst alternatywny }\end{array}$ & 9. Utwórz test \\
\hline \multirow[t]{3}{*}{ 10. Wyloguj się } & 10. Wpisz ocenę (oceń zadanie lub test) \\
\hline & 11. Sprawdź obecność \\
\hline & 12. Wyloguj się \\
\hline
\end{tabular}

Źródło: opracowanie własne

Zdefiniowanych zostało 7 zasad projektowania uniwersalnego (National Disability Authority, 2007):

- identyczne zastosowanie (ang. equitable use),

- elastyczność użycia (ang. flexibility in use),

- prosta i intuicyjna obsługa (ang. simple and intuitive),

— zauważalna informacja (ang. perceptible information),

— tolerancja błędów (ang. tolerance for error),

— niski poziom wysiłku fizycznego (ang. low physical effort),

— wymiary i przestrzeń do podejścia i użycia (ang. size and space for approach and use). 
World Wide Web Consortium (W3C), założona w 1994 roku, jest organizacją zajmującą się ustanawianiem standardów pisania i przesyłu stron www. Obecnie W3C zrzesza ponad 400 organizacji, firm, agencji rządowych i uczelni z całego świata. Niestety publikowane przez W3C rekomendacje nie mają mocy prawnej, nakazującej ich użycie. Mimo to twórcy stron, serwisów internetowych i innych materiałów umieszczanych w sieci zazwyczaj stosują wytyczne publikowane przez W3C, gdyż dzięki temu mogą zwiększyć grono odbiorców. Jedną z istotnych publikacji W3C jest zestaw trzech rekomendacji pod hasłem „Podstawowe elementy dostępności treści internetowych" (ang. Essential Components of Web Accessibility). Obejmuje ona następujące dokumenty:

- Wytyczne dotyczące dostępności narzędzi autorskich (ang. Authoring Tool Accessibility Guidelines ATAG),

- Wytyczne dotyczące dostępności treści internetowych (ang. Web Content Accessibility Guidelines WCAG),

- Wytyczne dotyczące dostępności narzędzi do przeglądania treści internetowych (ang. User Agent Accessibility Guidelines, UAAG).

Dokument ATAG wyjaśnia, jak uczynić narzędzia autorskie dostępnymi dla osób z niepełnosprawnościami, oraz pomaga twórcom na opracowywanie bardziej dostępnych treści internetowych (World Wide Web Consortium, 2015). Narzędzia autorskie są to aplikacje lub usługi wykorzystywane przez twórców treści internetowych, np. edytory HTML i XML, procesory tekstu, narzędzia formatowania CSS, narzędzia do transformacji dokumentów na formaty sieciowe, narzędzia do tworzenia plików multimedialnych, narzędzia do zarządzania witrynami. Rekomendacja ATAG 2.0 składa się z dwu części. Część A dotyczy tworzenia dostępnych narzędzi autorskich. Część B odnosi się do wykorzystania narzędzi autorskich do tworzenia dostępnej zawartości treści internetowych. ATAG 2.0 zawiera 24 wytyczne, dla których zdefiniowane są punkty kontrolne na trzech poziomach szczegółowości.

W badaniu oceniono pięć platform edukacyjnych: WIKAMP, Moodle, Sakai, Fronter i ItsLearning. WIKAMP, czyli WIrtualny KAMPus, jest to projekt realizowany przy współudziale pracowników Centrum Komputerowego Politechniki Łódzkiej oraz Instytutu Informatyki. Jego celem jest wdrożenie platformy e-learningowej opartej na platformie Moodle, która wspomaga proces kształcenia. $\mathrm{W}$ ramach projektu powstały serwisy internetowe skupiające $\mathrm{w}$ jednym miejscu wiele usług, takich jak informacje dla studentów, poczta elektroniczna, materiały edukacyjne. Każdy wydział Politechniki Łódzkiej dysponuje własną indywidualną platformą.

Moodle (ang. modular object-oriented dynamic learning environment) jest to system wspomagający proces zdalnego nauczania i uczenia się, dostępny przez przeglądarki internetowe (Sadzikowska, 2006). Moodle jest rozwiązaniem darmowym typu open source. Może być ono wykorzystywane zarówno do prowadzenia zajęć online, jak i do wspomagania i uzupełniania zajęć prowadzonych 
metodami tradycyjnymi. Moodle ma nieskomplikowany interfejs użytkownika dla przeglądarek internetowych i jest poddawany ciągłym modyfikacjom i pracy rozwojowej. Platforma ta jest używana nie tylko na uczelniach wyższych, ale też w szkołach podstawowych, gimnazjalnych i ponadgimnazjalnych. W testach wykorzystano wersję demo platformy.

Fronter to komercyjna platforma edukacyjna stworzona w Norwegii. Korzysta z niej ok. 6 milionów użytkowników. Cechą charakterystyczną platformy Fronter jest tzw. system otwarty. Oznacza to, że klienci mają dostęp do kodu źródłowego i mogą go modyfikować. Najczęściej jednak korzystają z usług dostawcy platformy, który dostosowuje system do potrzeb i wymagań użytkownika. Platforma Fronter jest wyposażona w blisko sto narzędzi podzielonych na pięć grup:

- praca własna,

- nauczanie i uczenie się,

- praca zespołowa,

— publikowanie (przygotowanie treści edukacyjnych i zarządzanie nimi),

— administrowanie platformą.

W testach została wykorzystana wersja platformy używana w Oslo and Akershus University College of Applied Sciences w Norwegii.

ItsLearning jest platformą edukacyjną opracowaną w Norwegii. Wykorzystywana jest w szkołach podstawowych, średnich i na uczelniach wyższych. ItsLearning oferuje funkcjonalność typową dla platform e-learningowych:

— komunikacja i współpraca online między uczniami i nauczycielami,

- administrowanie przedmiotami i ocenami,

- tworzenie materiałów źródłowych i naukowych, ich publikacja i zarządzanie nimi.

W testach została wykorzystana wersja platformy używana w University of Stavanger w Norwegii.

Sakai jest projektem zbliżonym programowo do Moodle. Jego cechą charakterystyczną jest zastąpienie luźnego powiązania między używającymi go jednostkami członkostwem wspólnotowym powiązanym z rozwojem platformy. W testach wykorzystano wersję demo platformy.

Zgodnie z rekomendacją ATAG zostało wytypowane jedenaście wytycznych, które zestawione są w tabeli 2.

Tabela 2. Zasady i wytyczne dostępności narzędzi autorskich zgodnie z rekomendacją ATAG 2.0 .

\begin{tabular}{l|l}
\hline \multicolumn{1}{c|}{ Zasada } & \multicolumn{1}{c}{ Wytyczna } \\
\hline $\begin{array}{l}\text { A.2. Zauważalność informacji zapewniana } \\
\text { przez narzędzia autorskie }\end{array}$ & $\begin{array}{l}\text { A.2.1. Tworzenie zawartości alternatywnej } \\
\text { (opis tekstowy dla obrazów i plików multi- } \\
\text { medialnych) }\end{array}$ \\
& $\begin{array}{l}\text { A.2.2. Dostępność edytora z poziomu róż- } \\
\text { nych modalności }\end{array}$ \\
\hline
\end{tabular}




\begin{tabular}{|c|c|}
\hline $\begin{array}{l}\text { A.3. Wykonalność operacji z wykorzystaniem } \\
\text { narzędzi autorskich }\end{array}$ & $\begin{array}{l}\text { A.3.1. Dostęp do narzędzi autorskich z kla- } \\
\text { wiatury }\end{array}$ \\
\hline & $\begin{array}{l}\text { A.3.2. Zapewnienie autorowi odpowiedniego } \\
\text { czasu na stworzenie zawartości }\end{array}$ \\
\hline & $\begin{array}{l}\text { A.3.3. Unikanie migających obrazów w tre- } \\
\text { ści, które mogą powodować ataki epilepsji. }\end{array}$ \\
\hline & $\begin{array}{l}\text { A.3.4. Nawigacja i edycja ułatwiona. przez } \\
\text { strukturę treści }\end{array}$ \\
\hline & A.3.5. Przeszukiwanie tekstu \\
\hline & A.3.6. Ustawienia preferencji \\
\hline & A.3.7. Podgląd tworzonych treści \\
\hline \multirow[t]{2}{*}{ A.4. Zrozumiałość narzędzi autorskich } & A.4.1. Obsługa błędów \\
\hline & A.4.2. Dokumentacja dla narzędzi autorskich \\
\hline
\end{tabular}

Źródło: opracowanie własne na podstawie rekomendacji ATAG 2.0. (World Wide Web Consortium, 2015).

\section{Ocena dostępności wybranych platform e-learningowych}

Wybrane platformy e-learningowe zostały przetestowane zgodnie z dwoma scenariuszami - dla ucznia i dla nauczyciela. Scenariusze były realizowane przez osoby testujące w trzech etapach z wykorzystaniem różnych zestawów urządzeń wejścia-wyjścia: (1) klawiatury, myszy komputerowej i monitora; (2) klawiatury i monitora; (3) klawiatury, myszy komputerowej i czytnika ekranowego. Wykorzystanie takich trzech sposobów komunikacji pozwoliło na ocenę dostępności wybranych platform edukacyjnych dla osób w pełni sprawnych, osób z niepełnosprawnościami ruchowymi, które nie mogą korzystać z myszy komputerowej, oraz osób niedowidzących i niewidomych. Dodatkowym elementem ewaluacji platform była ocena w skali 0-5 łatwości korzystania z systemu oraz projektu graficznego i rozmieszczenia elementów w interfejsie użytkownika. W testach brało udział pięć osób w grupie studentów i cztery osoby w grupie nauczycieli. Wszystkie osoby miały wcześniejsze doświadczenie w obsłudze platform e-learningowych. W kolejnych sekcjach opisane są wyniki przeprowadzonych testów oraz ocena wybranych platform edukacyjnych pod względem zgodności z zasadami projektowania uniwersalnego i wytycznymi rekomendacji ATAG. 


\subsection{Wyniki oceny wybranych platform wykonanej przez studentów i nauczycieli}

Osoby testujące wybrane platformy edukacyjne oceniały (1) możliwość wykonania zadania za pomocą trzech zestawów urządzeń wejścia-wyjścia oraz (2) łatwość wykonania zadania w skali 1-3. Zestawienie wyników testów wykonanych według scenariuszy (tabela 1) przez studentów i nauczycieli przedstawione jest w tabelach 3 i 4 . Oznaczenie skrótów w tabelach jest następujące: KMM - obsługa platform za pomocą klawiatury, myszy komputerowej i monitora; $\mathrm{KM}$ - obsługa platform za pomocą klawiatury i monitora; KMC — obsługa platform za pomocą klawiatury, myszy komputerowej i czytnika ekranowego. Poziom trudności wykonania zadania oznaczony jest jako: 1 - łatwo, 2 - średnio, 3 - trudno, 0 - niemożliwe do wykonania. Wartości przedstawione w tabelach są wartościami średnimi.

Tabela 3. Realizacja zadań scenariusza dla studenta

\begin{tabular}{|c|c|c|c|c|c|}
\hline Zadanie & WIKAMP & Fronter & Sakai & ItsLearning & Moodle \\
\hline & $\begin{array}{c}\mathrm{KMM} / \mathrm{KM} / \\
\mathrm{KMC}\end{array}$ & $\begin{array}{c}\mathrm{KMM} / \mathrm{KM} / \\
\mathrm{KMC}\end{array}$ & $\begin{array}{c}\mathrm{KMM} / \mathrm{KM} / \\
\mathrm{KMC}\end{array}$ & $\begin{array}{c}\mathrm{KMM} / \mathrm{KM} / \\
\mathrm{KMC}\end{array}$ & $\begin{array}{c}\mathrm{KMM} / \mathrm{KM} / \\
\mathrm{KMC}\end{array}$ \\
\hline 1. Zaloguj się & $1 / 2 / 2$ & $1 / 2 / 2$ & $1 / 1 / 1$ & $1 / 1 / 1$ & $1 / 1 / 1$ \\
\hline $\begin{array}{l}\text { 2. Dostosuj wy- } \\
\text { gląd interfejsu }\end{array}$ & $0 / 0 / 0$ & $0 / 0 / 0$ & $0 / 0 / 0$ & $0 / 0 / 0$ & $0 / 0 / 0$ \\
\hline $\begin{array}{l}\text { 3. Zmień dane } \\
\text { użytkownika }\end{array}$ & $1 / 1 / 1$ & $0 / 0 / 0$ & $0 / 0 / 0$ & $0 / 0 / 0$ & $1 / 1 / 1$ \\
\hline $\begin{array}{l}\text { 4. Wybierz } \\
\text { przedmiot }\end{array}$ & $1 / 1 / 1$ & $1 / 1 / 1$ & $1 / 1 / 1$ & $1 / 1 / 1$ & $1 / 1 / 1$ \\
\hline $\begin{array}{l}\text { 5. Otwórz plik } \\
\text { z tekstem }\end{array}$ & $1 / 1 / 1$ & $1 / 1 / 1$ & $1 / 1 / 1$ & $1 / 1 / 1$ & $1 / 1 / 1$ \\
\hline $\begin{array}{l}\text { 6. Otwórz } \\
\text { zadanie }\end{array}$ & $1 / 1 / 1$ & $1 / 1 / 1$ & $1 / 1 / 1$ & $1 / 1 / 1$ & $1 / 1 / 1$ \\
\hline $\begin{array}{l}\text { 7. Załaduj plik } \\
\text { tekstowy }\end{array}$ & $1 / 3 / 2$ & $2 / 3 / 2$ & $1 / 3 / 1$ & $1 / 3 / 1$ & $1 / 3 / 1$ \\
\hline $\begin{array}{l}\text { 8. Załaduj obraz } \\
\text { i dodaj opis }\end{array}$ & $1 / 3 / 2$ & $2 / 3 / 2$ & $1 / 0 / 2$ & $1 / 3 / 2$ & $1 / 3 / 2$ \\
\hline $\begin{array}{l}\text { 9. Załaduj } \\
\text { wideo i dodaj } \\
\text { opis }\end{array}$ & $0 / 0 / 0$ & $0 / 0 / 0$ & $0 / 0 / 0$ & $0 / 0 / 0$ & $0 / 0 / 0$ \\
\hline 10. Wyloguj się & $1 / 1 / 1$ & $1 / 1 / 1$ & $1 / 1 / 1$ & $1 / 1 / 1$ & $1 / 1 / 1$ \\
\hline
\end{tabular}

Źródło: opracowanie własne. 
Tabela 4. Realizacja zadań scenariusza dla nauczyciela

\begin{tabular}{|c|c|c|c|c|c|}
\hline Zadanie & WIKAMP & Fronter & Sakai & ItsLearning & Moodle \\
\hline & $\begin{array}{c}\mathrm{KMM} / \mathrm{KM} / \\
\mathrm{KMC}\end{array}$ & $\begin{array}{l}\mathrm{KMM} / \mathrm{KM} / \\
\mathrm{KMC}\end{array}$ & $\begin{array}{l}\mathrm{KMM} / \mathrm{KM} / \\
\mathrm{KMC}\end{array}$ & $\begin{array}{c}\mathrm{KMM} / \mathrm{KM} / \\
\mathrm{KMC}\end{array}$ & $\begin{array}{c}\mathrm{KMM} / \mathrm{KM} / \\
\mathrm{KMC}\end{array}$ \\
\hline 1. Zaloguj się & $1 / 2 / 2$ & $1 / 2 / 2$ & $1 / 1 / 1$ & $1 / 1 / 1$ & $1 / 1 / 1$ \\
\hline $\begin{array}{l}\text { 2. Dostosuj wy- } \\
\text { gląd interfejsu }\end{array}$ & $0 / 0 / 0$ & $0 / 0 / 0$ & $0 / 0 / 0$ & $0 / 0 / 0$ & $0 / 0 / 0$ \\
\hline $\begin{array}{l}\text { 3. Zmień dane } \\
\text { użytkownika }\end{array}$ & $1 / 1 / 1$ & $0 / 0 / 0$ & $0 / 0 / 0$ & $0 / 0 / 0$ & $1 / 1 / 1$ \\
\hline $\begin{array}{l}\text { 4. Wybierz } \\
\text { przedmiot }\end{array}$ & $1 / 1 / 1$ & $1 / 1 / 1$ & $1 / 1 / 1$ & $1 / 1 / 1$ & $1 / 1 / 1$ \\
\hline $\begin{array}{l}\text { 5. Załaduj plik } \\
\text { tekstowy }\end{array}$ & $1 / 2 / 2$ & $2 / 2 / 2$ & $1 / 2 / 1$ & $1 / 2 / 1$ & $1 / 2 / 1$ \\
\hline $\begin{array}{l}\text { 6. Załaduj obraz } \\
\text { i dodaj opis }\end{array}$ & $1 / 2 / 2$ & $2 / 3 / 3$ & $0 / 0 / 0$ & $1 / 2 / 1$ & $1 / 2 / 2$ \\
\hline $\begin{array}{l}\text { 7. Załaduj wideo } \\
\text { i dodaj opis }\end{array}$ & $1 / 2 / 2$ & $2 / 3 / 3$ & $0 / 0 / 0$ & $1 / 2 / 1$ & $1 / 2 / 2$ \\
\hline 8. Utwórz test & $1 / 2 / 1$ & $2 / 2 / 2$ & $1 / 2 / 1$ & $1 / 2 / 1$ & $1 / 2 / 1$ \\
\hline $\begin{array}{l}\text { 9. Utwórz zada- } \\
\text { nie tekstowe wg } \\
\text { wzoru }\end{array}$ & $1 / 0 / 1$ & $1 / 0 / 1$ & $1 / 0 / 1$ & $1 / 0 / 1$ & $1 / 0 / 1$ \\
\hline 10. Wpisz ocenę & $2 / 3 / 2$ & $1 / 1 / 1$ & $1 / 2 / 1$ & $1 / 1 / 1$ & $1 / 2 / 1$ \\
\hline $\begin{array}{l}\text { 11. Sprawdź } \\
\text { obecność }\end{array}$ & $1 / 3 / 1$ & $0 / 0 / 0$ & $0 / 0 / 0$ & $0 / 0 / 0$ & $0 / 0 / 0$ \\
\hline 12. Wyloguj się & $1 / 1 / 1$ & $1 / 1 / 1$ & $1 / 1 / 1$ & $1 / 1 / 1$ & $1 / 1 / 1$ \\
\hline
\end{tabular}

Źródło: opracowanie własne.

Logowanie do systemu w przypadku platform WIKAMP i Fronter jest dwuetapowe. W przypadku korzystania jedynie z klawiatury lub z czytnika ekranowego znacznie wydhuża to proces logowania. Żadna $z$ badanych platform nie umożliwia dostępu do ustawień graficznego interfejsu użytkownika. Zmiana rozmiaru czcionki, poziomu kontrastu lub kolorów możliwa jest jedynie z poziomu przeglądarki internetowej. Zmianę danych użytkownika możliwa jest w platformach Wikamp i Moodle. Pozostałe trzy badane systemy e-learningowe wymagają zgłoszenia danych do zmiany do administratora systemu. Wszystkie analizowane platformy umożliwiają stosunkowo łatwe wykonanie podstawowych operacji, takich jak załadowanie i otworzenie każdego rodzaju plików, bez względu na wykorzystywane narzędzia wejścia-wyjścia. Głównym problemem w przypadku obsługi platform za pomocą jedynie klawiatury było nieergonomiczne rozmiesz- 
czenie elementów w interfejsie użytkownika oraz problem z dostępem do menu edytorów tekstu, co uniemożliwiało odpowiednie formatowanie tekstu i wstawianie obrazów oraz plików multimedialnych.

\subsection{Ocena zgodności z rekomendacją ATAG}

Aby treści internetowe były dostępne dla każdego użytkownika bez względu na jego poziom sprawności psychofizycznej konieczne jest zastosowanie się do rekomendacji odnoszących się do dostępności systemów informatycznych. Użytkownik systemu informatycznego może być jednocześnie twórcą treści internetowych jak w przypadku nauczycieli tworzących zawartość przedmiotu w systemie e-learningowym. $Z$ tego powodu internetowe platformy edukacyjne powinny być zgodne z wytycznymi rekomendacji ATAG odnoszącej się do dostępności narzędzi autorskich, takich jak np. edytory HTML i XML, procesory tekstu, narzędzia formatowania CSS, narzędzia do transformacji dokumentów na formaty sieciowe, narzędzia do tworzenia plików multimedialnych czy narzędzia do zarządzania witrynami. Tabela 2 przedstawia zestawienie wybranych wytycznych rekomendacji ATAG, których implementacja w wybranych systemach e-learningowych została zweryfikowana podczas przeprowadzonych testów. W tabeli 5 przedstawione są kryteria odnoszące się do wybranych wytycznych, których spełnienie oceniane było w trakcie przeprowadzanych badań.

Tabela 5. Realizacja wytycznych ATAG 2.0

\begin{tabular}{l|l}
\hline \multicolumn{1}{c|}{ Wytyczna ATAG 2.0} & \multicolumn{1}{c}{ Realizacja } \\
\hline $\begin{array}{l}\text { A.2.1. Tworzenie zawartości alternatywnej } \\
\text { (opis tekstowy dla obrazów i plików multime- } \\
\text { dialnych) }\end{array}$ & $\begin{array}{l}\text { Dodanie opisów tekstowych do obrazów } \\
\text { i plików multimedialnych }\end{array}$ \\
\hline $\begin{array}{l}\text { A.2.2. Dostępność edytora z poziomu różnych } \\
\text { modalności }\end{array}$ & $\begin{array}{l}\text { Obsługa edytora z wykorzystaniem czytnika } \\
\text { ekranowego }\end{array}$ \\
\hline $\begin{array}{l}\text { A.3.1. Dostęp do narzędzi autorskich z kla- } \\
\text { wiatury }\end{array}$ & $\begin{array}{l}\text { Obsługa platformy z wykorzystaniem jedynie } \\
\text { klawiatury komputerowej }\end{array}$ \\
\hline $\begin{array}{l}\text { A.3.2. Zapewnienie autorowi odpowiedniego } \\
\text { czasu na stworzenie zawartości }\end{array}$ & $\begin{array}{l}\text { Autozachowywanie, automatyczne wylogo- } \\
\text { wywanie po określonym czasie bezczynności }\end{array}$ \\
\hline $\begin{array}{l}\text { A.3.3. Unikanie migających obrazów w treści, } \\
\text { które mogą powodować ataki epilepsji }\end{array}$ & $\begin{array}{l}\text { Autoodtwarzanie plików multimedialnych } \\
\text { możliwe do wyłączenia }\end{array}$ \\
$\begin{array}{l}\text { A.3.4. Nawigacja i edycja ułatwiona poprzez } \\
\text { strukturę treści }\end{array}$ & $\begin{array}{l}\text { Istnienie punktów nawigacyjnych na stronie } \\
\text { platformy }\end{array}$ \\
\hline A.3.5. Przeszukiwanie tekstu & $\begin{array}{l}\text { Opcja wyszukiwania zintegrowana z edyto- } \\
\text { rem/platformą }\end{array}$ \\
\hline
\end{tabular}


A.3.6. Ustawienia preferencji

Możliwość dostosowania kolorów, wielkości czcionki, rozmieszczenia elementów, edycji danych użytkownika

\begin{tabular}{l|l}
\hline A.3.7. Podgląd tworzonych treści & Opcja podglądu tworzonych treści \\
\hline A.4.1. Obsługa błędów & $\begin{array}{l}\text { Sprawdzanie pisowni, komunikaty o błędach, } \\
\text { możliwość cofnięcia wykonanej operacji }\end{array}$ \\
\hline A.4.2. Dokumentacja dla narzędzi autorskich & Dostęp do pomocy i dokumentacji \\
\hline
\end{tabular}

Źródło: opracowanie własne.

W przypadku wytycznej A.2.1., odnoszącej się do opisu tekstowego zawartości alternatywnej, takiej jak obrazy i pliki multimedialne, realizacja we wszystkich badanych platformach edukacyjnych była częściowa. W przypadku platform Moodle, Fronter, Wikamp i ItsLearning obowiązkowe jest dodanie opisu wszystkim plikom w przypadku dodawania ich z poziomu platformy. W platformie Sakai nie ma wymuszenia dodania opisów. Problemem jest brak możliwości dodania opisu zawartości alternatywnej dodawanej z poziomu edytorów tekstu, z których korzystają platformy, co uniemożliwia osobom niewidomym, korzystającym z czytnika ekranowego, zapoznanie się z zawartością obrazów lub plików multimedialnych umieszczanych $\mathrm{np}$. w testach lub ogłoszeniach.

Weryfikacja implementacji wytycznej A.2.2. została przeprowadzona z wykorzystaniem czytnika ekranowego. Problemem w przypadku wszystkich platform był brak informacji o błędach w pisowni, ponieważ podkreślenia błędów nie były widoczne w aplikacji czytnika ekranowego.

Wytyczna A.3.1. odnosi się do obsługi systemów jedynie za pomocą klawiatury. We wszystkich badanych platformach pojawiły się problemy przy obsłudze edytora tekstu, głównie z powodu braku dostępu do ikon umieszczonych w menu. Wytyczna A.3.4., odnosząca się do wspomagania nawigacji po stronie internetowej poprzez jej odpowiednią strukturę (grupowanie elementów, oznaczanie nagłówków), również ściśle wiąże się z obsługą platformy jedynie za pomocą klawiatury. We wszystkich badanych platformach wytyczna ta zaimplementowana jest częściowo, a nawigacja możliwa jest jedynie za pomocą klawiszy Tab, Shift+Tab, Enter, Esc i strzałek.

Automatyczne zachowywanie pracy (wytyczna A.3.2.) nie jest obsługiwane w platformach Fronter, Wikamp i ItsLearning, natomiast dla Moodle i Sakai jest ono dostępne po zainstalowaniu dodatkowej wtyczki. W przypadku platform Moodle, Wikamp i ItsLearning użytkownik nie jest informowany o automatycznym wylogowaniu po określonym czasie bezczynności.

Wyszukiwanie tekstu (A.3.5.) oraz ustawienia preferencji kontrastu i koloru (A.3.6.) w testowanych platformach realizowane jest we wszystkich przypadkach z poziomu przeglądarek internetowych. Problemem w przypadku platformy Moodle jest niekompatybilność w trybie zwiększonego kontrastu, co powoduje, 
że niektóre elementy przestają być widoczne, natomiast tryb ten nie jest realizowany w platformie Sakai.

Możliwość podglądu (A.3.7.) przygotowywanych treści istnieje w platformie Wikamp. W przypadku platform Fronter i ItsLearning nie ma opcji podglądu załadowanych plików, platforma Moodle nie obsługuje podglądu zawartości tekstowej, natomiast w systemie Sakai ta opcja nie jest zaimplementowana.

Wytyczna A.4.1. odnosi się do obsługi błędów w systemach. We wszystkich platformach zaimplementowane jest sprawdzanie pisowni $\mathrm{w}$ edytorach tekstu oraz możliwość anulowania akcji, jednak w żadnym z systemów nie ma komunikatu wymagającego potwierdzenie anulowania. W przypadku platform Fronter i Wikamp pojawia się problem z realizacją wytycznej A.4.2., gdyż dokumentacja platformy Fronter jest niekompletna, a dokumentacja platformy Wikamp nie jest dostępna.

\subsection{Ocena zgodności z zasadami projektowania uniwersal- nego systemów informatycznych}

Trzecim etapem oceny wybranych platform e-learningowych była weryfikacja ich zgodności z zasadami projektowania uniwersalnego (PU) systemów komputerowych. Uczestnicy badania zostali poproszeni o ocenę w skali 0-5 realizacji pięciu zasad PU, które zdefiniowane są w tabeli 6 . Najwyższą ocenę średnią (4.4.) wszystkich zasad uzyskała platforma ItsLearning. W przypadku platform Moodle, Wikamp i Sakai średnia ocena użytkowników jest taka sama, równa 3.8., co można thumaczyć tym, że platformy Wikamp i Sakai budowane są na silniku Moodle. Najniższą ocenę w testach, równą 3.6., uzyskała platforma Sakai. Wszystkie platformy działają poprawnie w różnych przeglądarkach internetowych, także dobrze została oceniona zaimplementowana obsługa błędów. Dość dużo problemów sprawiało użytkownikom korzystanie z platform przy użyciu jedynie klawiatury, gdyż część funkcji nie była dostępna. W przypadku platform opartych na silniku Moodle łatwość obsługi platformy została oceniona najniżej. Głównym powodem tego wyniku jest fakt, że wiele opcji jest dostępnych po wybraniu odpowiedniego trybu pracy (np. „włącz tryb edycji”) oraz są one umieszczone w interfejsie użytkownika w sposób mało intuicyjny.

Tabela 6. Realizacja zasad projektowania uniwersalnego w badanych platformach e-learningowych

\begin{tabular}{c|c|c|c|c|c}
\hline Zasada & WIKAMP & Fronter & Sakai & ItsLearning & Moodle \\
\hline $\begin{array}{c}\text { Średnia ocena interfejsu } \\
\text { graficznego platformy } \\
(0-5)\end{array}$ & 3 & 4 & 3 & 4 & 3 \\
\hline $\begin{array}{c}\text { Średnia ocena łatwości } \\
\text { obsługi platformy (0-5) }\end{array}$ & 3 & 3 & 4 & 5 & 3 \\
\hline
\end{tabular}




\begin{tabular}{c|c|c|c|c|c}
\hline $\begin{array}{c}\text { Zgodność funkcjonalno- } \\
\text { ści przy wykorzystaniu } \\
\text { różnych urządzeń wejścia- } \\
\text {-wyjścia (0-5) }\end{array}$ & 4 & 3 & 2 & 4 & 4 \\
\hline $\begin{array}{c}\text { Zgodność funkcjonalno- } \\
\text { ści platform w różnych } \\
\text { przeglądarkach interneto- } \\
\text { wych (IE, Chrome, Opera, } \\
\text { Firefox) (0-5) }\end{array}$ & 5 & 5 & 5 & 5 & 5 \\
\hline Obsługa błędów (0-5) & 4 & 4 & 4 & 4 & 4 \\
\hline
\end{tabular}

Źródło: opracowanie własne.

\section{Wnioski}

W pracy przedstawiono wyniki testów pięciu wybranych internetowych platform edukacyjnych pod względem ich zgodności z zasadami projektowania uniwersalnego oraz dostępności dla osób z różnymi rodzajami niepełnosprawności na podstawie realizacji wytycznych zawartych w rekomendacji ATAG 2.0. Większość wytycznych zrealizowana jest $\mathrm{w}$ badanych systemach e-learningowych częściowo, jednak możliwa jest skuteczna obsługa tych narzędzi za pomocą zarówno pełnego zestawu tradycyjnych urządzeń do komunikacji z komputerem (klawiatura, mysz komputerowa, monitor), jak i urządzeń wspomagających, takich jak czytnik ekranowy. Dostępność platform dla osób z niepełnosprawnościami ruchowymi została przetestowana na podstawie możliwości obsługi systemów tylko za pomocą klawiatury.

Przedstawione wyniki pokazują, że główne funkcjonalności platform dostępne są dla każdego użytkownika. Aby zapewnić pełną dostępność do badanych systemów e-learingowych i ich zgodność z wytycznymi zdefiniowanymi w rekomendacji ATAG 2.0., zdefiniowano następujące zalecenia:

- konieczność dodawania opisu plikom multimedialnym i obrazom, co umożliwi pełne zrozumienie treści użytkownikom głuchoniemym, niewidomym i niedowidzącym;

- grupowanie elementów, definiowanie nagłówków oraz znaczników podczas tworzenia interfejsów internetowych platform edukacyjnych, co ułatwi nawigację i obsługę tych systemów za pomocą kontrolerów alternatywnych przeznaczonych dla osób z niepełnosprawnościami ruchowymi;

— implementacja skutecznej funkcji wyszukiwania tekstu w obrębie treści zawartych w przedmiotach umieszczanych na danej platformie e-learningowej;

— możliwość personalizacji wyglądu interfejsu użytkownika, skrótów klawiszowych oraz parametrów czasowych w celu automatycznego zachowywania tworzonych treści i automatycznego wylogowywania, co ułatwi korzystanie z systemów wszystkim użytkownikom. 


\section{Bibliografia}

Chen W., Sanderson N.Ch., Kessel S. (2013), The accessibility of learning management systems from teachers 'perspective, Proceedings of the 21st International Conference on Computers in Education, s. 437-442.

Debevc M., Stjepanovič Z., Holzinger A. (2012), Development and evaluation of an e-learning course for deaf and hard of hearing based on the advanced Adapted Pedagogical Index method, „Interactive Learning Environments” 1, nr 22, s. 35-50.

Główny Urząd Statystyczny (2011), Stan Zdrowia ludności Polski w 2009 r., Warszawa, s. 69-75, stat.gov.pl/cps/rde/xbcr/gus/ZO_stan_zdrowia_2009.pdf [dostęp: 14.07.2016].

Habib L. et al. (2012), Dyslexic students in higher education and virtual learning environments: An exploratory study, „Journal of Computer Assisted Learning” 6, nr 28, s. 574-584.

Kicińska B. (19.06.2000). Wykorzystanie komputera wnauczaniu, http://oswiata.org.pl/uploadpub/258. doc [dostęp: 14.07.2016].

Laabidi M. et al. (2014), Learning technologies for people with disabilities, „Journal of King Saud University - „Computer and Information Sciences” 1, nr 26, suplement 29-45.

National Disability Authority (2007), The 7 Principles. Centre for Excellence in Universal Design, http://universaldesign.ie/What-is-Universal-Design/The-7-Principles/ [dostęp: 14.07.2016].

Periša M., Peraković D., Remenar V. (2011), Guidelines for developing e-learning system for visually impaired, Proceedings of International Conference on Universal Learning Design, s. 115-116.

Sadzikowska L. (2006), Platforma Moodle — dydaktyka przyszłości, „Gazeta Uniwersytecka UŚ” 136, nr 6, http://gazeta.us.edu.pl/node/229681 [dostęp: 14.07.2016].

Seale J., Cooper M. (2010), E-learning and accessibility: An exploration of the potential role of generic pedagogical tools, „Computers \& Education” 4, nr 54, s. 1107-1116.

Ulbricht V.R. et al. (2012), A tool to facilitate including accessible content in Moodle to the person with visual impairment, „Procedia Computer Science” 14, s. 138-147.

World Wide Web Consortium (2015), Authoring Tool Accessibility Guidelines (ATAG) 2.0, https:// www.w3.org/TR/ATAG20/ [dostęp: 14.07.2016]. 